\title{
APRESENTAÇÃO
}

\section{Mídia e memória: visibilidades e resistências}

Nas últimas décadas, a memória tem sido um objeto de representação recorrente em produções midiáticas, acompanhando o movimento de valorização do passado que emergiu nos discursos culturais e políticos do final do século XX. Nos diferentes trabalhos dedicados ao tema, como Seduzidos pela memória (2000) e Culturas do passado-presente (2014), Andreas Huyssen analisa a predominância do passado no presente a partir da formação de uma cultura e política da memória, e de sua globalização, refletindo sobre como a inter-relação da cultura memorialista com a indústria cultural e midiática transformou a memória em uma mercadoria consumida em massa e acabou por impulsionar também o esquecimento, com suas lembranças perecíveis. À cultura memorialística cruzam-se outros fenômenos contemporâneos que intensificam o protagonismo da memória na produção midiática, em especial a valorização da subjetividade e os novos ordenamentos de produção e consumo das artes, e da comunicação, propiciados pela era digital.

Se, por um lado, a massificação da memória pela indústria cultural e pela mídia promove sua banalização, os processos de revisão histórica realizados por minorias políticas e movimentos sociais, marcados por relatos pessoais e intenso recurso à memória, configuraram-se como uma forma de resposta e de resistência a políticas de silenciamento empreendidas por Estados e outros agentes políticos opressores. No contexto da América Latina, a subjetividade eclodiu especialmente na produção literária e audiovisual, por meio de narrativas biográficas e autobiográficas que demonstraram a importância das histórias pessoais e familiares para o alcance de visibilidade e participação na historiografia e escrita da memória nacional.

Nesse sentido, Beatriz Sarlo, em Tempo passado (2007), aponta que a valorização do testemunho como fonte para a reconstituição da história é um dos 
indícios da guinada subjetiva nos discursos contemporâneos, a qual abarca tanto a revalorização do indivíduo como a necessidade de reconstituição da verdade sobretudo histórica - a partir da rememoração da experiência. A memória individual converte-se, nesse contexto, em ferramenta política de contestação a versões oficiais da história e de acesso a outros pontos de vista, assim como permite recuperar histórias invisibilizadas ou que sofreram a tentativa de extinção, como a de indivíduos e comunidades socialmente marginalizados.

Acompanhando o movimento de subjetivação dos discursos e de protagonismo do passado no presente, a representação da memória em produções midiáticas tem se expandido para formatos não tão convencionais, como animações, quadrinhos, mídias digitais, podcasts e outros meios, revelando novos agentes produtores de conteúdo e inserindo outros pontos de vista nos discursos midiáticos. No conjunto dessas produções, destacam-se as narrativas que se movem entre os campos do factual e do ficcional, que mesclam convenções de gêneros estilísticos e adotam estruturas de produção mais horizontais, renovando tanto as abordagens discursivas como também as formas de produção e distribuição das mídias.

Dentro dessa conjuntura, este Dossiê tem como proposta apresentar reflexões sobre como a memória tem sido tensionada em produções culturais e midiáticas contemporâneas, por meio da produção de grandes veículos de comunicação ou de minorias sociais e ativistas políticos que recorrem ao poder eloquente do testemunho como arma para a promoção de políticas reparadoras, para a resistência a formas de opressão, afirmação identitária ou alcance de visibilidade social, com trabalhos em diferentes modalidades midiáticas e abordagens narrativas, sejam elas jornalísticas, literárias ou audiovisuais.

As relações entre mídia e memória são trabalhadas em diferentes perspectivas nos sete artigos que compõem o Dossiê, que se inicia com o texto "Mídia e memória da ditadura brasileira: a história e os usos políticos do passado", de autoria de Ana Paula Goulart Ribeiro e Rachel Berthol. Tendo em vista os modos de funcionamento das mídias e os estudos de memória, as autoras examinam a relação da mídia nacional com o atual momento de debates, disputas e tentativas 
de silenciamento do passado sobre a ditadura civil-militar brasileira, analisando o processo de conflito em torno da memória nacional sobre a ditadura, o qual se tornou mais intenso no governo de Jair Bolsonaro e na pandemia de Covid-19. Em sintonia, Cláudio Novaes Pinto Coelho aborda a memória da ditadura brasileira a partir de seu uso recente como estratégia de marketing pelo jornal Folha de S. Paulo, no artigo "A memória da ditadura militar e seu uso como estratégia de marketing na sociedade do espetáculo". Recorrendo a uma perspectiva histórica sobre os produtos midiáticos que tematizaram o período da ditadura militar, o autor analisa até que ponto as produções midiáticas produzidas no Brasil, especialmente a campanha do referido jornal, podem ser consideradas como contribuições reais para o conhecimento histórico desse período.

A memória como objeto de disputa na produção de sentidos é também tematizada por Mozahir Salomão Bruck, Herom Vargas, Jeane Moreira e em "Memória, poder e verdades: disputas de sentidos no acionamento do memorável no caso do Fundão", com a análise comparativa das narrativas divergentes do jornal comunitário $A$ Sirene e dos vídeos de storytelling da Fundação Renova, entidade responsável pela mobilização para a reparação dos danos causados pelo crime socioambiental ocorrido em Minas Gerais, com rompimento da Barragem do Fundão em 2015. Nesse texto, a memória dos moradores atingidos é matériaprima das produções midiáticas mencionadas e as diferentes abordagens revelam os conflitos, as disputas e os jogos de poder em torno da memória compartilhada sobre o ocorrido, ecoando as observações de Jacques Le Goff em História e memória (2003), sobre como a memória coletiva pode ser tanto um instrumento como um objeto de poder.

Em "Sarau Asas Abertas: memórias e resistência em forma de imagens visuais e de poemas", Barbara Heller, Vima Lia de Rossi Martin, Anderson William Marzinhowsky Benaglia e Fernanda Mendes Soares Barreiros chama atenção para a importância de grupos sociais excluídos e estigmatizados pelas mídias participarem na construção da memória coletiva, ao analisar as memórias produzidas por mulheres em situação de privação de liberdade publicadas no 
livro Sarau Asas Abertas, coletânea de poemas de mulheres aprisionadas na Penitenciária Feminina da Capital (PFC), em São Paulo. Os autores identificam no texto e imagens do livro o recurso à memória como estratégia de resistência à invisibilidade e ao silenciamento que essas mulheres enfrentam na sociedade, com uma estigmatização que repercute na abordagem de suas histórias pela imprensa de modo geral. A reação contra o silenciamento de um grupo socialmente marginalizado é tema também do texto de Guilherme Sfredo Miorando, "Os quadrinhos silenciosos contra a memória de silenciamento dos queer: identidade e sexualidade em Quadrinhos Queer", que analisa a expressão do silêncio em narrativas gráficas produzidas por pessoas queer, no livro Quadrinhos Queer, em correspondência com a falta de voz que elas sofrem socialmente. Nos quadrinhos silenciosos analisados pelo autor, a expressão da arte e da memória são meios para construir representações e representatividades, assim como para romper com o silenciamento social e com o senso comum envolvendo pessoas queer.

O conceito de "memória do futuro" é articulado no texto "Memórias do futuro, utopias e heterotopias em territórios rurbanos: os sete povos do norte de Minas", por Mônica Rebecca Ferrari Nunes, Marco Antonio Bin e Débora Regina Bacega, que analisaram a produção escrita e audiovisual disponível na internet de organizações não governamentais que atuam junto a comunidades tradicionais do norte de Minas. Buscando compreender como se dão as relações entre memória, utopia e heterotopias nos espaços dessas comunidades, as autoras e o autor examinaram como as memórias tradicionais das comunidades são convertidas em arquivos digitais e, articuladas com uma memória midiática, podem ser acessíveis no futuro. Fechando o Dossiê, Carlos Falci examina a produção recente da rede/coletivo de projecionistas "Projetemos", disponibilizada no Instagram, com a temática da pandemia da Covid-19 e da vacinação no Brasil, traçando uma relação entre projeções urbanas e memória. Considerando o perfil da rede "Projetemos" como um tipo de arquivo dinâmico, o autor investiga de que forma a memória da pandemia no Brasil é constantemente refeita, tanto de forma efêmera, nas projeções em espaços abertos, como de maneira perene, em plataformas de distribuição de conteúdo audiovisual da internet. 
A diversidade de produções - e de formatos artísticos e comunicacionais analisados pelas autoras e autores deste Dossiê - atesta como o interesse pela memória e sua interrelação com a produção midiática é um fenômeno que vem florescendo na era digital. O registro de memórias em produções artístico-culturais e no jornalismo, e a análise de discursos que atuam na construção e visibilização de memórias sob disputa, ignoradas ou silenciadas, constituem os principais objetos examinados pelos autores citados. Espera-se, com este Dossiê, apresentar uma contribuição para a ampliação e atualização dos estudos e reflexões sobre a conexão entre mídia e memória, expondo como essa relação se faz relevante para a compreensão dos processos sociais, culturais, identitários e históricos vividos hoje.

Jennifer Jane Serra Rosana de Lima Soares junho de 2021 